\title{
Dancing to the Rhythm of a Geiger Counter: Modern(ist) Narcissism and the Anthropo(s)cenic Shock
}

\section{João Florêncio}

Goldsmiths University of London

(j.florencio@gold.ac.uk)

\begin{abstract}
:
In 2011, the biggest nuclear accident since Chernobyl took place at the Fukushima Daiichi nuclear power plant in Japan. Soon after the nuclear accident, a video appeared on YouTube in which a rogue power plant worker walked towards one of the site's CCTV cameras and pointed to its centre while watching his own image being streamed live on his smartphone. Despite it clearly being a reinterpretation of Centers, the 1971 performance by Vito Acconci, this essay argues that the Fukushima reenactment not only questioned the cultural paradigms that grounded Acconci's original gesture, but also signaled the urgent need for humankind to reconsider its own ontological and epistemological grounds in the face of imminent extinction. By comparing Vito Acconci's Centers with its Fukushima reenactment, the essay tells the history of Modernity and of its failure as a project of human emancipation, grounded on a fantasy of human mastery of 'Nature.'
\end{abstract}

Keywords: Performance, Anthropocene, Modernity, Modernism, Acconci

(After the heathwaves: Heath Death, Entropy,

Absolute Zero...)

- Peter Reading ${ }^{1}$

\section{Setting the Scene}

On the 11th of March 2011, at exactly 14:46 JST, the Pacific Coast of Tōhoku in the Northeast of Honshu, Japan, was hit by the 9.0 magnitude-strong Great East Japan Earthquake. Immediately after the beginning of the seismic activity, the emergency shutdown system of the Fukushima Daiichi Nuclear Power Plant, located in the most affected coastal area, went into operation in Units 1, 2, and 3, which were active at the time. ${ }^{2}$ However, due to the severity of the tremors, the electricity transmission between the Tokyo Electric Power Company Shinfukushima Transformer Substations and the Fukushima Daiichi Nuclear Power Plant was also damaged, resulting in a total loss of electricity and in the consequent automatic activation of the emergency diesel generators, which were responsible for powering the core cooling down process in the three active reactors. ${ }^{3}$ Following from this, and as it is often the case, a major tsunami was formed as a consequence of the disturbances in the oceanic crust and reached its peak at 15:37 JST. As if the damage caused by the earthquake hadn't already been enough, the tsunami flooded and destroyed the emergency diesel generators of the nuclear power plant, along with its seawater cooling pumps, the electric wiring system, and the DC power supply for Units 1, 2, and 4. By the time the water had retreated, the site was powerless and full of debris, and its monitoring equipment was left irresponsive. ${ }^{4}$ Ultimately, the lack of electricity made it extremely difficult to cool down the reactors and the lack of access made it harder to bring in cooling alternatives such as fire trucks. As a result, a series of reactor core exposures and damages started at approximately 18:10 JST in Unit 1, followed by Unit 2 at 9:10 on the 13th of March, and Unit 3 at approximately 17:00 on the 14th. These events led to hydrogen explosions at the Unit 1 building

$\overline{1}$ Peter Reading, -273.15 (Tarset: Bloodaxe Books, 2005), 1.

2 See Japan, NAIIC, The Official Report of The Fukushima Nuclear ACcident Independent Investigation Commission (Tokyo: The National Diet of Japan, 2012), 23-24.

4 Ibid. 
on the 12th of March, at Unit 3 on the 14th, and at Unit 4 on the 15th, followed by an explosion and mass discharge of radioactive material from Unit 2 also on the 15 th. $^{5}$ It is estimated that a total of $900 \mathrm{PBq}$ of radioactive substances were released, $1 / 6$ of the emissions of the Chernobyl accident, leading the Japanese government to evacuate 146,520 people living within a $20 \mathrm{Km}$ radius of the power plant, several foreign embassies to advise their citizens to evacuate areas extending as far as Tokyo, and the disaster to be rated 7- "Major Accident" - on the International Nuclear and Radiological Event Scale. ${ }^{6}$ According to the World Nuclear Association, most radioactivity accumulated in the soil was due to the release of Caesium-137, an easily dispersible radionuclide with a 30-year half-life, which can contaminate land for some time and, due to its solubility, end up being consumed by humans. ${ }^{7}$ In July 2011 , data collected by the Japanese Government identified the presence of accumulated Caesium-137 at radioactivity levels ranging between $10 \mathrm{KBq}$ and $3000 \mathrm{KBq} / \mathrm{m}^{2}$ in locations up to $80 \mathrm{Km}$ away from nuclear power plant. ${ }^{8}$ Although the levels of radioactivity were much lower than those released during the archetypical nuclear accident that was Chernobyl, and even if there is no consensus amongst experts on the long-term health effects of exposure to low radiation levels, Chernobyl has taught the world that the levels of radioactivity accumulated in mountain and forest areas do not naturally diminish for many decades, and that wildfires, floods, and other events, whether natural or not, can cause the contamination to spread even further. ${ }^{9}$ Still, one cannot as yet know what long-term consequences will the radioactivity released during the Fukushima Daiichi Nuclear Disaster have both on the humans that were exposed to it and on future human generations. And neither can we predict with absolute certainty how far will the radioactivity reach and for how long. Nevertheless, one thing is already certain amidst all that uncertainty: in June 2013, a paper was published by scientists at the University of the Ryukyus in Okinawa, presenting the outcomes of a series of physiological and genetic tests done to the Zizeeria maha, a pale grass blue species of butterfly common in Japan which, like all butterflies more generally, is used as an indicator species in the evaluation of environmental conditions. ${ }^{10}$ The results were clear: not only were mild morphological abnormalities found in $12.4 \%$ of the individuals caught in 7 localities near Fukushima in May 2011, but, perhaps most importantly, those abnormalities were inherited by their second generation, which also presented a much higher overall rate of abnormalities at $33.5 \%{ }^{11}$ What that shows is that, only two months after the Fukushima accident, the local ecosystems had already been forever changed as a result of the spread of artificial radionuclides.

\section{Exterior. Nuclear Site.}

Soon after the Fukushima nuclear disaster a video appeared on YouTube in August 2011 and quickly went viral. In it, a power plant worker wearing full protection clothing is seen walking towards one of the power plant's CCTV cameras in the aftermath of the explosions and radioactive discharge. Carrying in his hand what seemed to be a smartphone streaming live images from that particular CCTV camera, the worker uses the live stream on his mobile device to help him position himself at the centre of the frame in the foreground of the image. Behind and besides him, the otherwise vegetal landscape is punctuated by metal pipes and vertical steel structures. As soon as the worker is positioned at the centre of the screen, he opens his right arm 45 degrees to the side and pauses there, pointing to the site on which he stands. After a few seconds he raises his arm up to the sky and then down again towards the front until his index finger is pointing at the centre of the camera. As he stays there, his right index finger pointing at the camera, his left hand holds his phone close to his face so he sees the live streaming. After about 20 minutes, he leaves.

Image 1: anonymous worker points a finger at a monitoring live camera, Fukushima 1 nuclear plant, 2011. Video still.

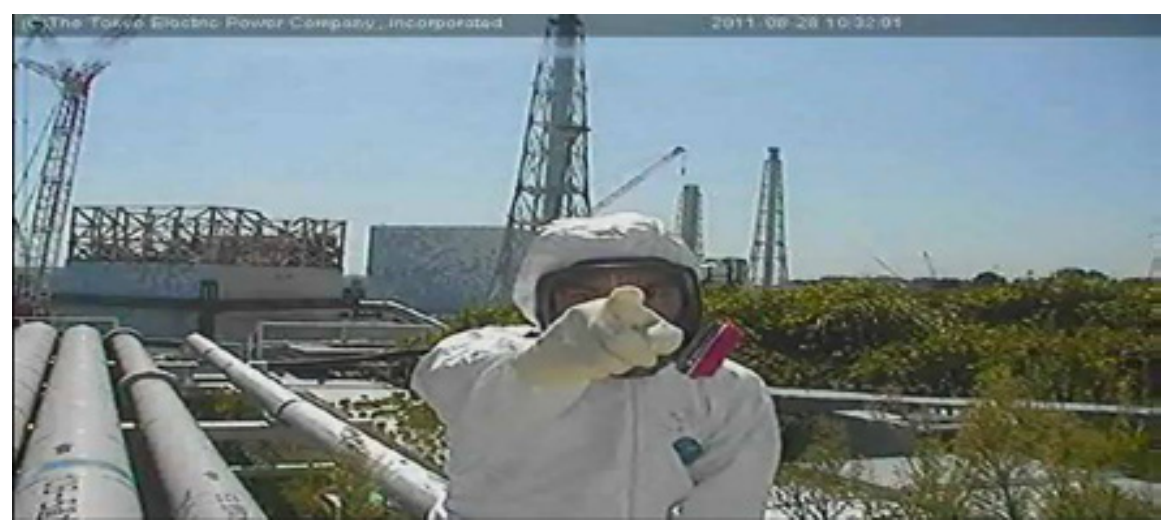

5 Ibid.

6 Ibid., 34. See also Rama C. Hoetzlein, "Visual Communication in Times of Crisis: The Fukushima Nuclear Accident," Leonardo 45, no. 2 (2012): 113 and World Nuclear Association, "Fukushima Accident 2011," http://www.world-nuclear.org/info/Safety-and-Security/Safety-of-Plants/

Fukushima-Accident-2011/ [accessed April 3, 2013].

World Nuclear Association, "Fukushima Accident 2011."

8 NAIIC, The Official Report of The Fukushima Nuclear Accident Independent Investigation Commission, 40.

9 See lbid.

${ }^{10}$ See Atsuki Hiyama et al., "The biological impacts of the Fukushima nuclear accident on the pale grass blue butterfly." Scientific Reports 2 , no. 570 (2012): 1 .

11 Ibid., 2, 5 . 
After the video went viral and started attracting the attention of internet users worldwide, the media, and even TEPCO and the Japanese government, the mysterious worker reemerged in late 2011, this time online, with a a blog on which he published documentation and texts on the now infamous event, and acknowledged it was a reenactment of Vito Acconci's 1971 work Centers, adapted to the site of the Fukushima nuclear crisis and the present global time of the Internet and closed-circuit surveillance systems. ${ }^{12}$

The worker's reference to Vito Acconci became less of a surprise after March 2012, when Tokyo-based artist Kota Takeuchi announced his intention of including the Fukushima CCTV video in a solo exhibition he was due to hold in Japan's capital city. ${ }^{13}$ Soon, all the speculation on the identity of the worker seemed to have turned into a safe degree of certainty. Although Takeuchi still refused to confirm he was the man pointing at the CCTV camera even after having announced the inclusion of the video in his solo show, the news stories ran by media titles such as The Japan Times seemed to leave little room for doubt: according to the newspaper not only was 29-year-old Takeuchi about the same hight and built as the rogue Fukushima worker, but he had also admitted to having been working at the power plant at the time the video was shot. ${ }^{14}$ Little room for doubt, then-the Fukushima CCTV video had been officially recognised as art.

With such qualifier grounding the visioning of the video and with its reassuring passage from the anonymity of the internet to the signed white walls of a Tokyo art space, a few questions arise: to which extent did the radioactive spatiotemporal context of Takeuchi's video added to, expanded, or problematised the original gesture of Vito Acconci? In what way or ways does the viewing of a man pointing at himself pointing at the centre of a screen acquire a new set of possible readings when it is framed by the anxious clicks of a geiger counter? What happens to Acconci's video when the man who reenacts it stands on the contaminated grounds of a nuclear disaster? Or, ultimately, if Acconci's Centers is agreed upon as a paradigmatic moment of late Modernity, what can Takeuchi's video tell us about the urgencies of our own present time?

\section{Interior. White Cube.}

When, in 1971, Vito Acconci decided to sit in front of a television connected to a video camera and film himself pointing at the centre of the screen that, in turn, was showing his own mirror-image, live, pointing back at himself, time stopped and the whole ethos of Modernity was condensed in the 20-minute duration of the video-performance.

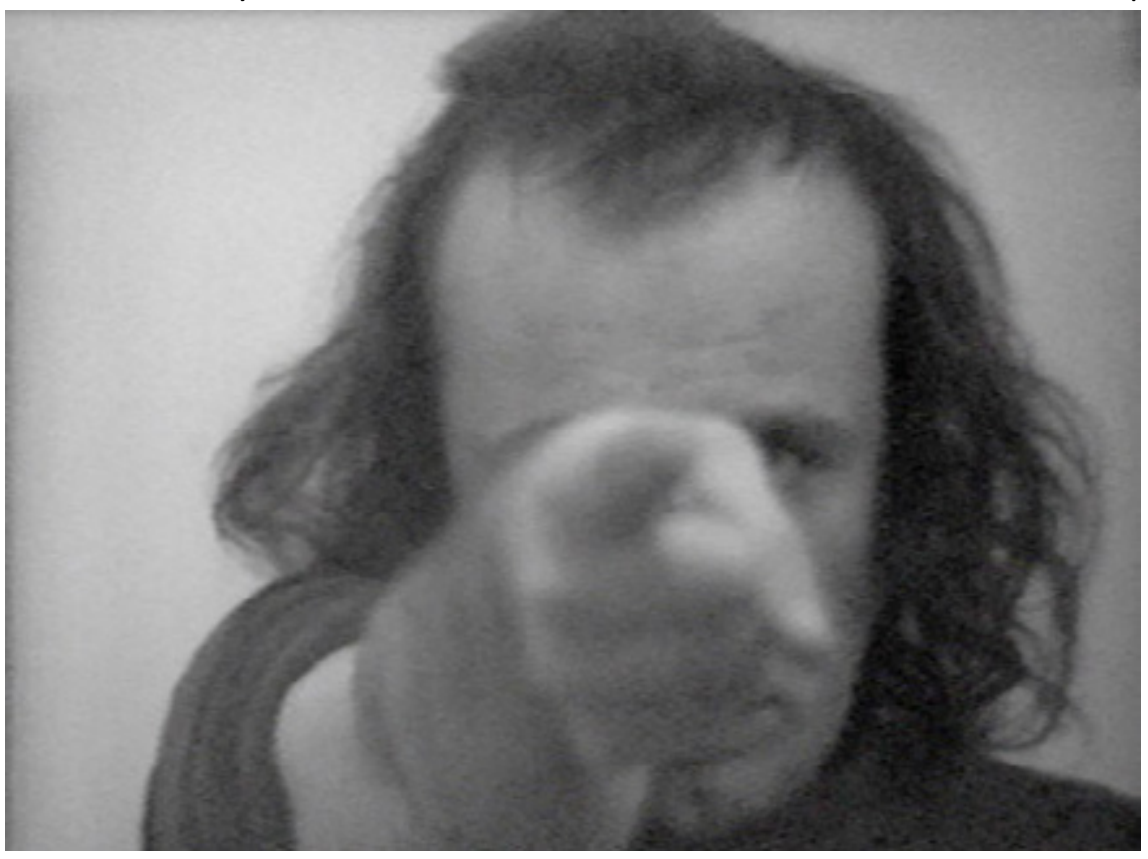

Image 2: Vito Acconci, Centers, 1971. Video Still.

According to Rosalind Krauss, writing five years later, in 1976, in the first issue of October, Acconci's work, a "sustained tautology: a line of sight that begins at Acconci's plane of vision and ends at the eyes of his projected double" is a paradigmatic example of the "narcissism so endemic to works of video." ${ }^{15}$ It is because Centers reveals the human

15 Rosalind Krauss, “Video: The Aesthetics of Narcissism," October 1 (1976): 50. 
body bracketed from its environment by being caught within the feedback loop of a visual apparatus that is able to simultaneously record and transmit images, that Krauss uses it as the ultimate example of video's underlying narcissism. Whereas established art forms such as painting, sculpture, or even film, defining themselves through the exploration of the material specificities of their particular medium, in video work the artist is left surrounded only by him or herself, eventually collapsing the present through self-encapsulation, spatial closure, and self-reflection. ${ }^{16}$ Like the lake that reflects Narcissus back to himself, video is, according to Krauss, revelatory of a self that is "split and doubled by the mirror-reflection of synchronous feedback". ${ }^{17}$

Through his use of a mirroring apparatus, Acconci staged the fusion of the artist with his own artwork. In Krauss' words,

[the] self and its reflected image are of course literally separate. But the agency of reflection is a mode of appropriation, of illusionistically erasing the difference between subject and object. Facing mirrors on opposite walls squeeze out the real space between them. ${ }^{18}$

Although it is not hard to follow Rosalind Krauss' view of Vito Acconci's Centers as a paradigmatic instance of the narcissistic obsession with specular images, it is less easy to agree with what she saw as video's rupture with the ethos and aesthetics of modernist art practices or, at least, with Modernism as it was theorised by modernist art critics. Even if in Centers the object did indeed reflect back the narcissistic subject, it is difficult to accept that such a mirroring was not a logical development of Modernism itself and that, as such, its relation with the artistic gestures found previously in modernist art was one of rupture rather than continuity. Such continuity could have been easily recognised by Krauss had the art critic taken into consideration the ideology on which Modernism and Modernity more broadly have been grounded since their inception as, respectively, artistic and civilisational projects. In other words, had Rosalind Krauss looked at modernist art in the context of the broader project of Modernity, she would have had to at least recognise the possibility that Acconci's work and the narcissism which she identified in video were both not a break away from but, rather, the logical culmination of a long social, political, and artistic enterprise, the history of which started around the same time Immanuel Kant answered the question "What is Enlightenment?"

\section{Narcissist Modernity}

According to Kant, the Age of Enlightenment was the moment in history when humankind realised that freedom and autonomy were its ultimate destiny. Answering the question Was ist Aufklärung? in 1874 in the newspaper Berlinische Monatschrift, Kant famously started by stating that "[enlightenment] is man's [sic] emergence from his self-incurred immaturity. Immaturity is the inability to use one's own understanding without the guidance of another." ${ }^{19}$ Strongly grounded on his own philosophical project, Kant's answer to the question "What is Enlightenment?" saw as the ultimate task of humankind to reach for perfection through the pursuit of autonomy and the free use of reason. It was reason that, from the moment in which it was awaken in the history of humankind, led humans to raise themselves above other animals by allowing them to project themselves into a freer, righteous and fairer future, and, as a consequence, to separate themselves from the natural environment through the realisation that humankind itself was the "true end of nature." ${ }^{20}$ However, because thought has its own limits, Enlightenment was not only a programme aimed at the progressive liberation of reason and, as a consequence, of man, but it was also, and because of that, a project of critique, of recognising the barriers which thought must not cross if it is to produce valid knowledge. ${ }^{21}$ It was there that Kant placed his own Critiques. Widely recognised as the inaugural texts of Modernity understood as a set of social and political values and as an epistemological attitude grounded on a critical ethos, Kant's three Critiques were written as a field guide for what is knowable and what is, instead, ungraspable. One of their most striking conclusions was

16 Ibid., 53-54.

17 Ibid., 55.

18 Ibid., 56-57.

19 Immanuel Kant, An Answer to the Question: What is Enlightenment?, trans. H.B. Nisbet (London: Penguin Books), 1.

20 Ibid., 94.

21 As Michel Foucault has put it:

Kant in fact describes Enlightenment as the moment when humanity is going to put its own reason to use, without subjecting itself to any authority; now it is precisely at this moment that the critique is necessary, since its role is that of defining the conditions under which the use of reason is legitimate in order to determine what can be known, what must be done, and what may be hoped. Illegitimate uses of reason are what give rise to dogmatism and heteronomy, along with illusion; on the other hand, it is when the legitimate use of reason has ben clearly defined in its principles that its autonomy can be assured. The critique is, in a sense, the handbook of reason that has grown up in Enlightenment; and, conversely, the Enlightenment is the age of critique. Michel Foucault, "What is Enlightenment?", in The Politics of Truth, ed. Sylvère Lotringer (Los Angeles: Semiotext(e), 2007), 104. 
that, because the mind is only able to grasp the world through appearances that are passed on to it by the senses and organised under conceptual categories by understanding, knowledge of nature is only valid as long as it is understood as knowledge of things qua objects of experience and not knowledge of things in themselves. In other words, because things in themselves are outside the mind and are only able to be judged once they have been converted into thoughts, thought is only ever able to think thought and never the things outside thought to which thought itself refers. ${ }^{22}$ Given that time and space or, in other words, duration and extension, are a priori concepts of understanding that precede empirical reality, Kant defined his Transcendental Idealism as the doctrine that all appearances are regarded as mere representations, not as things in themselves, and that space and time, therefore, are only sensible forms of our intuition, not determinations given independently by themselves, or conditions of objects taken as things in themselves. ${ }^{23}$

Following from the above, it is possible to identify the formation of a double separation of humans from 'Nature' in Kant's project for Enlightenment: not only are humans separated from it once through the development of their exclusive high mental faculties, but those mental faculties themselves, due to the conditions that must be in place for their correct operability, end up producing a second kind of separation, this time a separation of thought from world in itself. It is this twice-enforced divide between human and world that can still be seen today as the epistemological paradigm grounding a great amount of work that falls under critique, a dominant methodology of scholarly work that is perhaps better illustrated by Michel Foucault's archaeology of knowledge.

In his rethinking of Kant's answer to the question of what is Enlightenment, Foucault saw Kant's original text as the first time a philosopher has connected his work on knowledge with a reflection on history and on the particular moment in which and because of which he is writing. ${ }^{24}$ It was because Kant saw his own age as calling for humankind to fulfil its duty of pursuing freedom through Enlightenment, that Foucault characterised the German philosopher as being the point of departure of the "attitude of modernity." ${ }^{25}$ Modernity was, according to Foucault, an attitude because it was, first and foremost, a way of conceiving one's own time in relation to humanity's progression towards emancipation. Such attitude was not circumscribed in time because the project of critique was seen by Foucault as still ongoing: humankind was yet to reach its final cause, Enlightenment. It was, thus, in line with that ongoing critical enterprise that Foucault placed his own work, albeit with a crucial difference separating it from Kant's. Whereas Kant used critique in order to map the limits of a necessarily finite knowledge, Foucault put critique at the service of a genealogy of the present in order to demonstrate the historical contingency of knowledge and to then consider the possibility of breaking away from it. Like Foucault, himself, wrote:

But if the Kantian question was that of knowing what limits knowledge has to renounce transgressing, it seems to me that the critical question today has to be turned back into a Positive one: in what is given to us as universal, necessary, obligatory, what place is occupied by whatever is singular, contingent, and the product of arbitrary constraints? The point, in brief, is to transform the critique conducted in the form of necessary limitation into a practical critique that takes the form of a possible transgression. ${ }^{26}$

It is Foucault's openly political version of critique that can be found today across academia. From Feminism to Queer Theory, from Deconstruction to Postcolonial Theory, the critical ethos of the Humanities, much indebted to Foucault's work, has taken as its primary role to reflect upon the limits of human knowledge in order to understand how what is taken for granted is indeed produced at the level of discourse through complex articulations of power and knowledge. Foucault's critical project, as it was seen, was one that aimed to reveal how knowledge, rather than describing a stable and graspable exterior reality, is indeed responsible for its production. As Deleuze put it, in Foucault the "subject is a variable, or rather a set of variables of the statement. It is a function derived from the primitive function, or from the statement itself." ${ }^{27}$ By focusing on the performativity of knowledge, the critical project seeks to reveal how realities previously assumed to be universal are instead produced by knowledge itself. In other words, the aim of critique is that of revealing how, to quote Eve Sedgwick, "knowledge does rather than simply is." ${ }^{28}$ To this primacy of the revelatory,

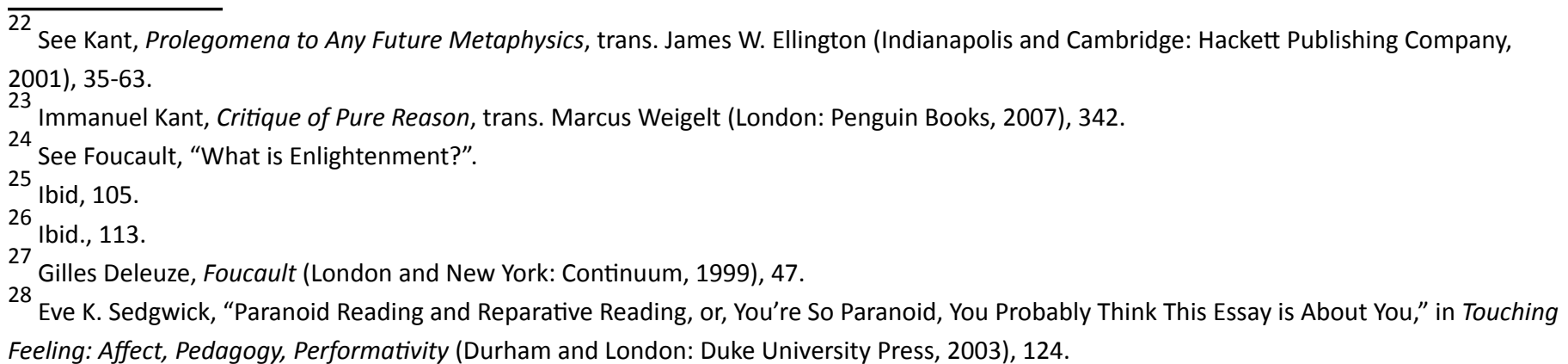


Sedgwick gave the name "paranoid reading" and characterised it as a "hermeneutics of suspicion," a term borrowed from French philosopher Paul Ricour. ${ }^{29}$ By privileging how knowledge performs the world rather than merely reflecting it, suspicion has taken over criticality, ultimately becoming an obstacle to its own project of separating the contingent from the universal. In other words, contemporary critique, in all its suspicion, ended up betraying itself by only allowing as certain the claim upon which critique itself depends for its own survival, i.e. the one that posits the historical contingency and performative nature of all knowledge. As Sedgwick asked, "Always historisize? What could have less to do with historicizing than the commanding, atemporal adverb 'always'?"30

Sedgwick's diagnosis of the state of contemporary critique is also shared by French sociologist Bruno Latour. In the aftermath of $9 / 11$ and as a response to the overwhelming proliferation of conspiracy theories pointing to 'the real' masterminds behind the attacks on the World Trade Center and the Pentagon, Latour wrote a piece for Critical Inquiry in which he examined the role critique had played in his own work and the ways in which uncritical suspicion has become the dominant feature of criticality. Giving as an example French philosopher Jean Baudrillard's claim that "the Twin Towers destroyed themselves under their own weight, [...] undermined by the utter nihilism inherent in capitalism itself," Latour argued that critique has become synonym with "instant revisionism" and inundated both academia and the non-academic public sphere with more or less sophisticated conspiracy theories. ${ }^{31}$ The problem is that whereas the critical enterprise had, since the dawn of Enlightenment, been concerned with disputing systems of beliefs such as those advocated by various religious doctrines and replacing them with scientifically validated facts, at the start of the 21st century and there being no beliefs left to disprove, critique has now started targeting facts themselves, often by negating their existence or by turning them into a mere product of their dialectical counterpart, the observing human subject and its world-making language..$^{32}$

The unfortunate outcome of that phenomenon is clear: while scholars spend their time trying to reveal the arbitrary nature of everything other than the critical enterprise itself, very real phenomena are having rather real consequences: global warming is happening, the Arctic ice cap is melting, natural resources are diminishing, sea levels are rising, and old and new pandemics are killing millions (unless you can pay to survive). The most obscene aspect of the unrestrained reign of critique is that, as Latour argued, it has gone from being a progressive, left-wing enterprise to having become the weapon of choice of conservative rhetorics, one that is used to discredit everything from the existence of global warming to the true causes of the 2008 banking crisis. ${ }^{33}$ In short, widespread critique has become the cause of society's inability to act upon issues as pressing as persisting social inequalities or climate change. In the 21st century the only thing humanity seems to be able to do is to argue while hoping that one day the cows will eventually come home (by themselves).

Granted, such such ethos of radical and widespread critique has brought undeniable benefits to human societiesfrom highlighting the nature of gender and ethnic inequalities to actively challenging the colonialist and Eurocentric structures of power that still operate today. Nevertheless, it has done so at the expense of its being able to make claims about anything other than knowledge itself: through its exclusive focus on relations of (human)power-(human) knowledge, critique has been unable to address anything beyond its human door step. In other words, because the critical attitude of Modernity has restricted itself to reflecting upon the limits of human knowledge as a way of driving (human) emancipation and freedom, it has progressively lost contact with the reality of the nonhuman 'outside' against which modern man had defined himself. As a necessary result of the modern narratives of progress towards autonomy and of the split between 'Nature' and "Culture," humankind is today alienated from everything other than itself, living

29 Ibid.

30 Ibid., 125

31 Bruno Latour, "Why Has Critique Run out of Steam? From Matters of Fact to Matters of Concern," Critical Inquiry 30 (2004): $228-229$.

32 This is how Latour put it:

I want to show that while the Enlightenment profited largely from the disposition of a very powerful descriptive tool, that of matters of fact, which were excellent for debunking quite a lot of beliefs, powers, and illusions, it found itself totally disarmed once matters of fact, in turn, were eaten up by the same debunking impetus (Ibid., 232).

33

As an example, in is essay for Critical Inquiry, Latour quoted a New York Times editorial from the 15 of March, 2003 :

Most scientists believe that [global] warming is caused largely by man-made pollutants that require strict regulation. Mr. Luntz [a Republican strategist] seems to acknowledge as much when he says that "the scientific debate is closing against us." His advice, however, is to emphasize that the evidence is not complete.

"Should the public come to believe that the scientific issues are settled," he writes, "their views about global warming will change accordingly. Therefore, you need to continue to make the lack of scientific certainty a primary issue" (Ibid., 226). 
in a house of mirrors where every single wall reflects back a version of ourselves and where the only possible task seems to be that of realising which of those reflections are true and which ones are, instead, fictitious. And so, the modern human, pilgrim of progress and reason, was left unable to grasp anything other than itself: its qualities, its capacities, its politics, its beauty. Like Narcissus stuck by the lake or-better-like Narcissus drowning in the lake, breathing the liquid of its own reflection (and happy ever after), civilisation keeps on going until the day comes when, after the heat waves and after all the heat deaths, we reach absolute zero.

\section{Specular Modernism}

In the previous section Modernity was seen driven Humanity into narcissism. In what follows, attention will be paid to how the narcissist attitude of modernity manifested itself in its art, leading modernism to become, paradoxically perhaps, yet another human mirror despite the supposed progression towards aesthetic autonomy that culminated in abstraction. In short, how was it that, unlike what was put forward by Rosalind Krauss, Vito Acconci's Centers did not represent a break with Modernism but was, instead, the fulfilment of Modernism's own unsung promise?

In order to answer the above question, one needs to start by looking at the most prominent advocate of modernist art: Clement Greenberg. Known for having defined Modernism as the culmination of art's path towards autonomy, Greenberg claimed that not only was Modernism a direct result of art's pursuit of autonomy but, very much like Kant and Foucault, it also had critique as its preferred method..$^{34}$ It was because Modernism was primarily a self-critical project that artists eventually turned their attention away from representations of everyday life and started instead focusing on the limits of their particular media.

Almost two decades later, in 1980, Michael Fried, also him a modernist critic and very much indebted to Greenberg, traced art's pursuit of autonomy all the way back to the latter part of 18th-century France. ${ }^{35}$ What Fried identified in French painting of that time was the beginnings of a tendency to paint figures in a state of what he called "absorption," i.e., figures 'behaving' as if the beholder was not present. Referencing Jean-Baptiste Greuze's Un Père de famille qui lit la Bible à ses enfants, Fried noted that,

each figure in the painting appeared to exemplify in his or her own way, i.e., the state or condition of rapt attention, of being completely occupied or engrossed or (as I prefer to say) absorbed in what he or she is doing, hearing, thinking, feeling. ${ }^{36}$

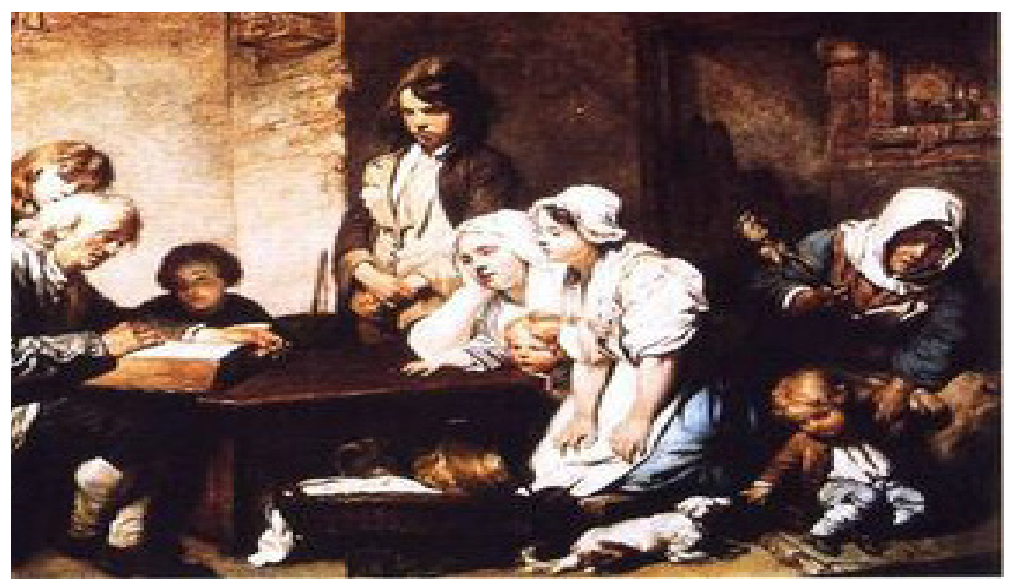

Image 3: Jean-Baptiste Greuze, Une Père de Famille qui Lit la Bible à ses Enfants, 1755. Oil on canvas. Private Collection.

\footnotetext{
34 In his words:

Modernism used art to call attention to art. The limitations that constitute the medium of painting - the flat surface, the shape of the support, the properties of pigment-were treated by the Old Masters as negative factors that could be acknowledged only implicitly or indirectly. Modernist painting has come to regard these same limitations as positive factors that are to be acknowledged openly. Clement Greenberg, "Modernist Painting," in Modern Art and Modernism: A Critical Anthology, eds. Francis Frascina and Charles Harrison (London: Paul Chapman Publishing, 1988), 6.

35 Michael Fried, Absorption and Theatricality: Painting and Beholder in the Age of Diderot (Berkeley, Los Angeles, and London: University of California Press, 1980), 1.

36 Ibid., 10.
} 
According to his argument, that tendency appeared in France as a reaction against Rococo style which was predominant at the time. In order to illustrate that point, Fried quoted Diderot's devastating critique of Rococo painter François Boucher in which the author of $L$ 'Encyclopédie criticised the way the former painted children "frolicking on clouds" and never "studying a lesson, reading, writing, stripping hemp." ${ }^{37}$

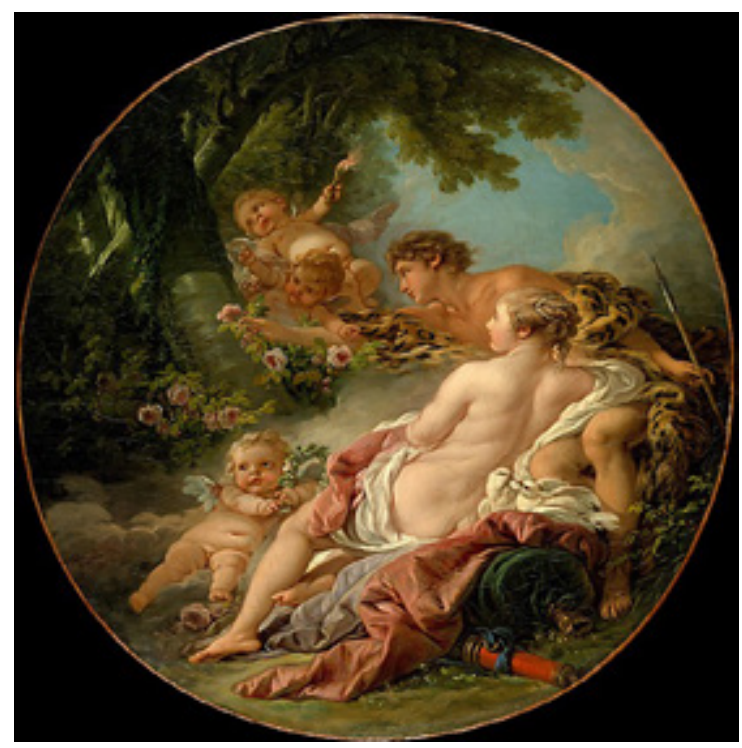

Image 4: François Boucher, Angélique et Médor, 1763. Oil on canvas. Musée du Louvre.

In Rococo painting, the figures seemed to exist in function of the beholder, they seemed to do nothing but 'posing' for him or her. According to Fried, what Diderot valued instead were figures fully absorbed in their own lives, figures that seemed oblivious to the fact that they were being looked at. In other words, and this is the crux of Fried's argument, it was because the figures of Greuze and Chardin "treated the beholder as if he were not there," that their paintings can be seen as marking the beginning of art's progression towards autonomy from life, where 'life' is indexed by the presence of the beholder. ${ }^{38}$

However, what Fried seemed to overlook in his thesis was that, rather than calling for art to detach itself from life, what Diderot really intended was to strengthen the ties binding the two. By calling for the depiction of everyday scenes in painting and for a theatre that was oblivious of its audience, Diderot was not invoking art's autonomy avant la lettre but was instead favouring realist subject matters and naturalist acting as a tool of public education in the context of a growing bourgeois polis. ${ }^{39}$ Rather than proposing that art should emancipate itself from life, Diderot's plan was for art to embrace life in its subject matter and assume a didactic function.

This tension between claims of art's autonomy on the one hand, and an emphasis on its didactic function on the other, can also be traced all the way back to Kant. At the beginning of his Critique of Judgement, Kant famously made a case for aesthetic's autonomy from life by claiming that judgements of taste are independent from all individual interests and desires. In other words, in order for a judgement of taste to be pure, a representation must be contemplated without influence from one's interest (or the lack of it) in the thing represented. ${ }^{40} \mathrm{It}$ is because judgements of taste are independent from personal interest that they must remain the same for everybody and, thus, be universal. ${ }^{41}$ However, on $\S 59$, Kant makes a crucial move, whereby he claims that, although beauty is autonomous from personal interests, it is nevertheless "a symbol of morality," i.e. of practical reasoning. ${ }^{42}$ By this the philosopher means that the beautiful and the moral are analogous to one other, that is, their operation follows similar rules so that "the agreement [between the

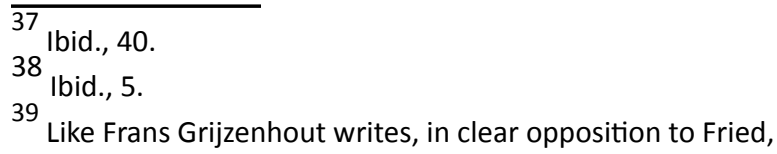

For Diderot, life and truth were the ultimate objectives of art. He eschewed excessively complex allegory and symbolism. In number 314 of his Pensées détachées fur la peinture, he pointed to the Dutch painter De Lairesse, whose pictures are often beautiful but whose themes are obscure. By depicting 'honest' and 'simple' subjects realistically, the artist could hit what should be his true target, namely the heart of the viewer.Diderot hoped this would inspire the public to such things as filial and parental love, domestic happiness, and integrity. Frans Grijzenhout, "Between Reason and Sensitivity: Foreign Views of Dutch Painting, 1660-1800," in The Golden Age of Dutch Painting in Historical Perspective, eds. Frans Grijzenhout and Henk van Veen (Cambridge: Cambridge University Press, 1999$), 27$.

40 See Immanuel Kant, Critique of Judgement, trans. James C. Meredith (New York: Oxford University Press, 2007), 36-37.

41 lbid., 42-43.

42 Ibid., 178. 
two] is merely in the form of reflection, and not in the content." ${ }^{43}$ Put very simply, when judging the beautiful, pleasure derives from the fact that the "freedom of the imagination [...is...] represented as in accord with the understanding's conformity to law," 44 whereby the understanding's "conformity to law," means its recognition of the "purposiveness of both nature and art." 45 Therefore, in a judgement of taste, one experiences personal freedom (of the imagination) while nevertheless abiding by external universal a priori laws (those recognised by understanding in 'Nature' and art). Beauty is, thus, a symbol or metaphor of morality because, when acting morally, one's will is also free despite the fact that "the objective principle of morality is set forth as also universal, i.e. for all individuals, and, at the same time, for all actions of the same individual". 46

That apparent tension between art's autonomy from life and its role as an agent of Enlightenment was in fact concomitant with the values and ideology of the emerging bourgeois order. As Peter Bürger notes in his Theory of the Avant-Garde, art's supposed emancipation from life was deeply contradictory: whereas, on the one hand, the Kantian moment was responsible for inaugurating modernist aesthetic with its defence of art's autonomy from life and, consequently, of the universality of the aesthetic judgement, on the other it was clearly the product of particular historical and social events by being deeply connected with the desire of the bourgeoisie to replace the individual interests of the Ancient Régime with the universality of Reason and moral law. ${ }^{47}$

Given the above, it is reasonable to argue that, far from being detached from life, modernist art was in fact inseparable from it. In other words, rather than being autonomous from (human) life, modern art played an essential role in emancipating Humanity from 'Nature' by wrapping the former in an opaque layer of reassuring mirror-images. And so, the path that, following Michael Fried, had led from Greuze and Chardin to abstract expressionism was the exact same path that led Vito Acconci into the narcissistic loop of his own reflection.

\section{The Anthropocenic Shock}

Driven by humanity's pursuit of autonomy, it was Modernity that, through its cutting of the Gordian knot that tied humans to nonhumans, eventually brought about capitalism and liberalism. In line with Modernity's programme for an autonomous humankind, capitalism unfolded with the promise of shifting man's exploitation of man towards man's exploitation of 'Nature.' By seeing nature as the great outside rich in resources waiting to be exploited as fuel for the progress of humans and the accumulation of capital, capitalism thrived on the idea that the route towards the emancipation of all humans could only pass through a rise in the production of goods made possible by an intensification in the exploitation of 'Nature.'

The problem was that Modernity and capital did not manage to put a stop to man's exploitation of man and to bring about the autonomy that Modernity dreamt for all humans; on the contrary, capital has simply shifted exploitation to the global south, to those geographies at the fringes of the 'civilised' modern world where people live unaccounted for, uncared for, nonhumanly. And, similarly, humankind has in recent decades been forced to recognise not the limits of its own knowledge that the critical project sought to reveal but, instead, the reality of our imminent catastrophic extinction, triggered as it is by feedback loops resulting from our own disregard of the planet and unsustainable exploitation of its resources, driven by fantasies of teleological progress and economic growth. That is the shock of the Anthropocene, the time when the edges of the human-inflicted cut between 'Nature' and 'Culture' are finally reconnected albeit at the expense of a rather painful scar.

Writing in 2002 in Nature, chemist Paul Crutzen proposed to assign the term "Anthropocene" to "the present, in many ways human-dominated, geological epoch, supplementing the Holocene-the warm period of the past 10-12 millenia." ${ }^{48}$ Crutzen's proposed to set the beginning of the Anthropocene around 1784, the year when James Watt first designed the steam engine and when analyses of air trapped in polar ice first revealed growing global concentration of carbon dioxide. ${ }^{49}$

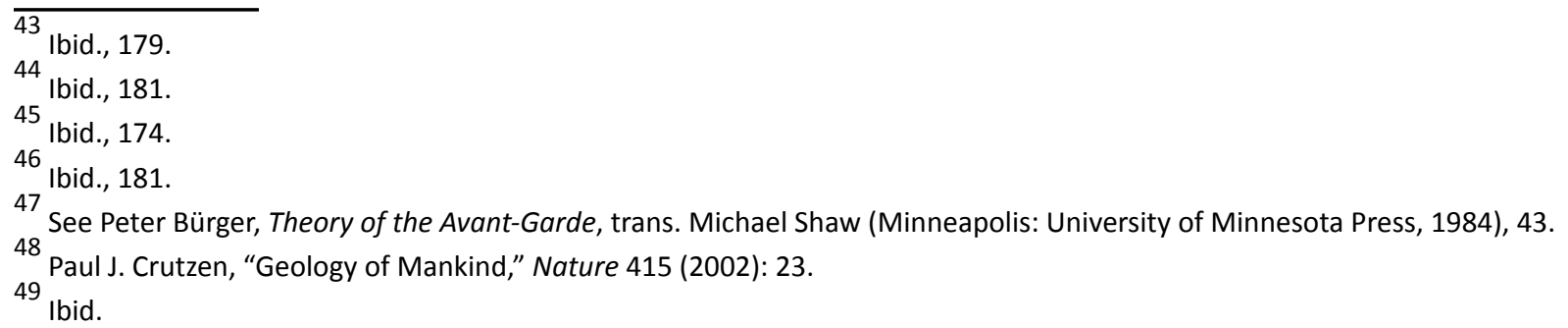


According to data quoted by Crutzen, since the dawn of the industrial revolution in Britain, the human population increased tenfold to 6 billion, being expected to reach 10 billion before the end of the 21st century. Driven by changes in the human dietary habits made possible by the industrialisation of human food supply chains, the methaneproducing cattle population has risen to 1.4 billion and the fishing industry has removed more than $25 \%$ of the primary fish production in upwelling ocean regions and $35 \%$ in the temperate continental shelf, while $30-50 \%$ of the planet's land surface is being exploited by humans. While damns and river diversions have been made possible thanks to the development of engineering and become common realities around the globe with cities like London having its small rivers now flowing through underground systems, tropical forests are disappearing and more than half of all accessible fresh water is being used by humans. Energy use has increased 16-fold during the twentieth century, leading to the emission of 160 million tonnes of atmospheric sulphur dioxide per year, more than twice the sum of its natural emissions, while more nitrogen fertiliser is applied in agriculture than is able to be fixed naturally by all terrestrial ecosystems. Added to that, fossil-fuel burning and agriculture have caused substantial increases in the concentration of greenhouse gases-carbon dioxide by $30 \%$ and methane by more than $100 \%$, reaching their highest levels of the past 400 millennia. As a consequence of all those effects, caused so far by only $25 \%$ of the world population, the Earth's climate is changing dramatically and faster than it ever did in the previous 12 millennia of the Holocene, with global warming, climate change, and carbon emissions now often coming at the top of party-political debates. ${ }^{50}$

In what can be seen as the planet's response to the modern dream of human autonomy, the Anthropocene on which we now stand has showed us that 'Culture' and 'Nature' are deeply entangled in one another. While Modernity fed on the dream of a human existence twice split from the real thanks to its mastery of reason and ethos of permanent critique, the Anthropocene has proved that emancipation and eventual human autonomy are impossible tasks in a world in which everything is always-already enmeshed in everything else, forming networks of systems and environments from which no single thread can safely be removed without the danger of the whole fabric falling apart.

\section{Walking on thin ice}

If Vito Acconci's Centers highlighted the narcissism of Modernity, what does the reenactment of that gesture in Fukushima tell us about a humanity awaken to the reality of the Anthropocene? Although at first both gestures seemed to trigger similar narcissistic loops, a few differences between the two point to the significant gap between original and reenactment. In Acconci's video, the frame was occupied exclusively by a close-up of the artist against a white wall, his face and pointing finger at the centre of the screen. In the Fukushima video, on the other hand, the artist occupied only a small fraction of the frame and was surrounded by a very specific and identifiable environment, the Fukushima power plant. Whereas Acconci's video was filmed in the clinical, sanitised white cube of a generic art gallery, its reenactment in 2011 was captured by CCTV in the contaminated site of a nuclear disaster. If the image of Acconci dominated Centers, the radioactive landscape of Fukushima dominated its reenactment, eventually troubling the certainty of the human figure and its reassuring presence. Also, whereas Acconci's body was caught in the closed circuit of early video technology, framed by the camera on one side and by the television screen on the other, the existence of the Fukushima video was expanded in time and in space, 'viralised' thanks to the Internet and YouTube, able to be played in every single corner of the world at the same time, forever. In other words, whereas Acconci's loop only included the artist, the camera, the TV screen, and a very localised group of spectators (the ones watching the video in the gallery), the Fukushima reenactment, although also circular, by its being almost immediately uploaded onto YouTube, it was able to circulate in a much larger network and thus to implicate individuals and geographies that could otherwise be seen as detached from Fukushima and the clicks of its Geiger counters.

Finally, one small but crucial difference separates Acconci's performance from its nuclear reenactment, a difference in the pointing gesture itself: whereas Vito Acconci raised his arm upwards and forwards until it was pointing at the exact centre of the frame, the Fukushima worker initially raised his arm to the side, pointed to the site on which he stood, and only afterwards finalised the gesture by rotating his arm upwards along his side and then downwards along the front towards the centre of the frame, in a folding gesture that stressed the enmeshment of Fukushima, the Tokyo Electric Power Company, the Great Eastern Japan Earthquake, "green" nuclear energy, cesium-127, himself, and all his viewers in the global ecological crisis. 


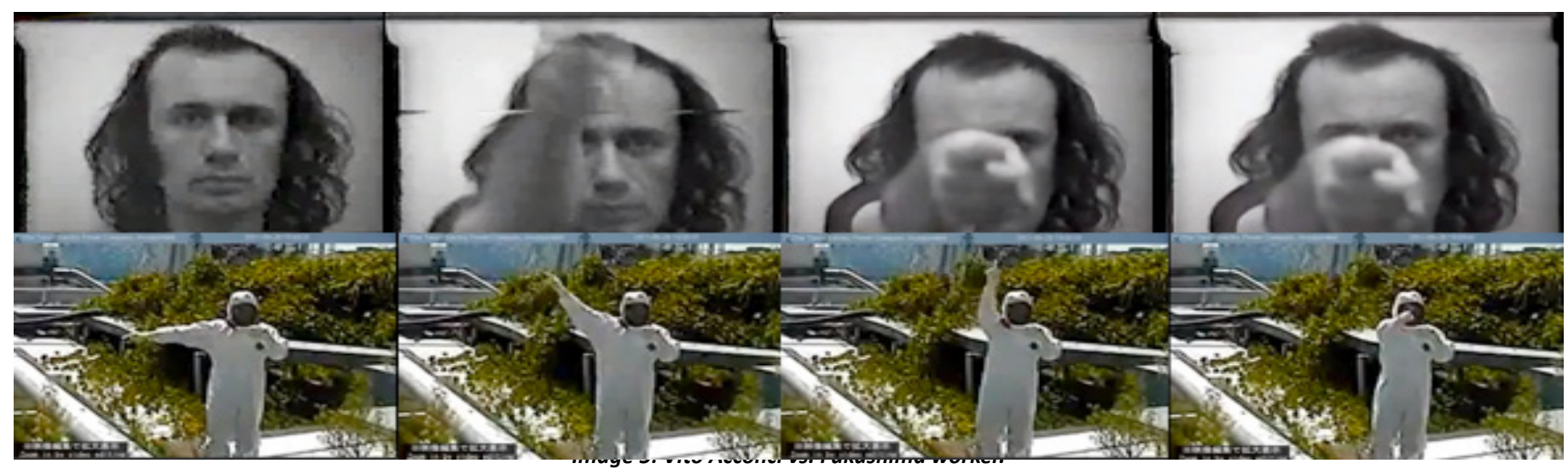

Therefore, whereas Centers revealed narcissism as the condition of Modernity, its reenactment in Fukushima replaced self-assuring narcissism with anxiety, the latter being the symptom of a time when progress and civilisation seem to have failed and the reality of an anthropogenic end of days becomes not a matter of 'if' but rather one of 'when.' While Modernity was leading humanity to fall in love with its own ego-ideal, the Anthropocene was progressively settling in to remind us of our inability to flee the global ecological catastrophe for which we have contributed. Eventually, the promises of modern narcissism gave way to the extinction anxiety of a species being forced to face the certainty of its own demise. In the end, after the heathwaves, the certainty of absolute zero.

João Florêncio is a final-year doctoral candidate in the Department of Visual Cultures at Goldsmiths, University of London, where he is rethinking existing theories of performance from within an ecological framework that rejects the rigidity of existing divides between 'Nature' and 'Culture.'

\section{References}

Bürger, Peter. Theory of the Avant-Garde. Minneapolis: University of Minnesota Press, 1984.

Corkill, Edan. "Are we Pointing at the Right Guy?" The Japan Times, March 8, 2012.

Crutzen, Paul J. "Geology of Mankind." Nature 415 (2002): 23.

Deleuze, Gilles. Foucault. London and New York: Continuum, 1999.

Foucault, Michel. "What is Enlightenment?". The Politics of Truth, edited by Sylvère Lotringer, 97-119. Los Angeles: Semiotext(e), 2007.

Fried, Michael. Absorption and Theatricality: Painting and Beholder in the Age of Diderot. Berkeley, Los Angeles, and London: University of California Press, 1980.

Greenberg, Clement. "Modernist Painting." In Modern Art and Modernism: A Critical Anthology, edited by Francis Frascina and Charles Harrison, 5- 10. London: Paul Chapman Publishing, 1988.

Grijzenhout, Frans. "Between Reason and Sensitivity: Foreign Views of Dutch Painting, 1660-1800." In The Golden Age of Dutch Painting in Historical Perspective, edited by Frans Grijzenhout and Henk van Veen, 11-28. Cambridge: Cambridge University Press, 1999.

Hoetzlein, Rama C. "Visual Communication in Times of Crisis: The Fukushima Nuclear Accident." Leonardo 45, no. 2 (2012): 113-118. 
Hiyama, Atsuki et al. "The biological impacts of the Fukushima nuclear accident on the pale grass blue butterfly." Scientific Reports 2, no. 570 (2012): 1-10.

Japan, NAIIC. The Official Report of The Fukushima Nuclear Accident Independent Investigation Commission. Tokyo: The National Diet of Japan, 2012.

Kant, Immanuel. Prolegomena to Any Future Metaphysics, translated by James W. Ellington. Indianapolis and Cambridge: Hackett Publishing Company, 2001.

—. Critique of Pure Reason, translated by Marcus Weigelt. London: Penguin Books, 2007.

—. Critique of Judgement, translated by James C. Meredith. Oxford: Oxford University Press, 2007.

—. An Answer to the Question: What is Enlightenment?, translated by H. B. Nisbet. London: Penguin Books, 2009.

Krauss, Rosalind. "Video: The Aesthetics of Narcissism." October 1 (1976): 50-64.

Latour, Bruno. "Why Has Critique Run out of Steam? From Matters of Fact to Matters of Concern." Critical Inquiry 30 (2004): 225-248.

n.a. "About the Pointing a Finger Toward Fukushima live cam." Accessed April 3, 2013. http://pointatfuku1cam. nobody.jp/e.html.

Reading, Peter. -273.15. Tarset: Bloodaxe Books, 2005.

Sedgwick, Eve K. "Paranoid Reading and Reparative Reading, or, You're So Paranoid, You Probably Think This Essay is About You." In Touching Feeling: Affect, Pedagogy, Performativity, 123-151. Durham and London: Duke University Press, 2003.

World Nuclear Association. "Fukushima Accident 2011." Accessed April 3, 2013. http://www.world-nuclear.org/info/ Safety-and-Security/Safety-of-Plants/Fukushima-Accident-2011. 